AGRO EKONOMI, Vol 30, Issue 2, December 2019, Page.125-138

DOI : http://doi.org/10.22146/ae.49014

ISSN 0215-8787 (print), ISSN 2541-1616 (online)

Available at https://jurnal.ugm.ac.id/jae/

\title{
COMPETITIVENESS OF INDONESIAN CRUDE COCONUT OIL EXPORT IN DESTINATION COUNTRIES
}

\author{
Tri Fatma Mala Yulhar ${ }^{1}$, Dwidjono Hadi Darwanto ${ }^{2}$ \\ ${ }^{1}$ Master Student in Agricultural Economics, Faculty of Agriculture, \\ Universitas Gadjah Mada \\ ${ }^{2}$ Departement of Socioeconomics, Faculty of Agriculture, Universitas Gadjah Mada \\ Jl. Flora No. 1 Bulaksumur, Yogyakarta \\ tri.fatma.m@mail.ugm.ac.id
}

Submitted : 26 August 2019 ; Revised : 10 October 2019;

Accepted : 11 November 2019

\begin{abstract}
This study aims to examine the competitiveness of Indonesian CCO in destination countries and examine what factors influencing the competitiveness of Indonesian CCO in destination countries. The analytical methods used in this research were RCA, EPD, and panel data regression analysis. The time period used in this research was 1996 to 2017. The results of the study concluded that Indonesian CCO had competitiveness in the United States, the Netherlands, Malaysia, China, and Singapore. RCA index in each destination country showed that Indonesian CCO had a very strong comparative advantage. The EPD analysis shows that Indonesian CCO was in a rising star position in the Netherlands, Malaysia, China, and Singapore, while in the United States market Indonesian CCO was in a falling star position. The export volume of Indonesian CCO had positive effect, while trade openness of importing countries and export value of Philippines CCO had negative effect on the competitiveness of Indonesian CCO. The government and CCO exporters need to lobby the destination countries to import CCO from Indonesia, and to convince the destination countries, the quality of the CCO needs to be improved, so that Indonesian CCO will become more competitive than others.
\end{abstract}

Keywords: CCO, competitiveness, export, RCA

Yulhar, T.F.M., \& Darwanto, D.H (2019) Competitiveness Of Indonesian Crude Coconut Oil Export In Destination Countries. Agro Ekonomi 30(2), 125-138.

\section{INTRODUCTION}

One of the leading commodities of Indonesian plantations is coconut (Cocos nucifera L). Crude Coconut Oil (CCO) is a part of processed coconut which has the highest economic value and contributes greatly to the overall export of Indonesian coconut products.
The demand for coconut oil in the world is increasing along with the increasing demand for vegetable oil in the world as a source of alternative energy raw materials. According to Sukmaya (2017) palm oil, rapeseed, and soybean dominate the demand of vegetable oil in the international market. However, 
the existence of negative environmental issues in the land clearing of palm oil plantation and the decline in soybean production have become a matter of great concern by importing countries, so the permits of the exporting countries of the two vegetable oil producers are very strict. Therefore, coconut oil is considered to be one of the alternative vegetable oils which is environmentally friendly and not too competitive as a staple food such as soybean.

Coconut oil is widely used as raw material for food and non-food industries such as cooking oil, cosmetics, pharmaceuticals, soap making, and biodiesel technical fuel (Kementerian Perdagangan, 2013). The high potential of using coconut oil will certainly be very promising and able to increase markets, especially in industrialized countries. Indonesia has the potential to develop CCO exports to the international markets and the destination contries. Indonesia is not only one of the countries with the largest coconut harvest area in the world (3.26 million ha), but also the highest coconut producer (18.98 million tons) in the world (FAOSTAT, 2019). However, at present, Indonesia only contributes $23 \%$ to the world CCO demand. This value is still far lower than the Philippines as the world's main supplier of $\mathrm{CCO}$ with a contribution of $61 \%$. Other competing countries, such as Sri Lanka, the Netherlands, and
Malaysia contributed 5\%, 2\%, and 2\% to the world CCO demand, the remaining $7 \%$ was completed by other countries (UNComtrade, 2019).

The research regarding the demand for Indonesian CCO in the international market during 1980-2005 had been conducted by Turukay (2009) and it was found that export prices and domestic prices of Indonesian CCO, soybean oil price, GDP of importing country, currency exchange rate, RCA index and dummy variable (transition of palm oil as a major supplier of cooking oil) had significant effect on export demand of Indonesian CCO. Futhermore, Djoni et al. (2013) found that export prices of Indonesian CCO, population and GDP real per capita of importing countries, real exchange rate, and export prices of Philippines CCO influenced the export volume of Indonesian CCO in four major importing countries (the Netherland, China, Malaysia, and Singapore).

The success of a country in the international trade can be seen from its export competitiveness (Bustami and Hidayat, 2013). The previous research on Indonesian CCO is still limited to the determinant of export volume and there were no studies on the determinant of Indonesian CCO competitiveness in destination countries yet, including the United States. So, this study discusses about the competitiveness of Indonesian 
$\mathrm{CCO}$ and examine what factors influence the competitiveness of Indonesian CCO in the destination countries. In addition, this research will also examine how trade openness of importing countries affects the competitiveness of Indonesian CCO. Trade openness, known as increasing flows of international trade, is considered to bring changes to economic growth and competitiveness (Pilinkiene, 2016). Hence, it becomes an important determinant to observe how it affects the competitiveness of Indonesian CCO.

\section{METHODS}

The data used in this study were secondary data (table 1 ). The time series data for 22 years (1996-2017) was used to analyze CCO export competitiveness, and the panel data analysis was used to analyze factors affecting the export competitiveness of Indonesian CCO in destination countries. Five destination countries (the United States, the Netherlands, Malaysia, China and Singapore) were chosen based on the order of the export value of Indonesian CCO to the destination countries and their continuity during 1996-2017. In addition, selected countries were also export destination countries from the Philippines, with the aimed to see the impact of the main competitors on the competitiveness of Indonesian CCO.
Analytical Framework Analysis competitiveness of Indonesian CCO to destination countries

Revealed Comparative Advantage (RCA) is a method of competitiveness analysis to measure the comparative advantage that reflects the competitiveness of a product with other products in the world export market (Sari and Hartono, 2010). The calculation of the RCA index, formulated by Balassa (1965) as follows:

$$
\mathrm{RCA}=\frac{\mathrm{X}_{\mathrm{ij}} / \mathrm{X}_{\mathrm{t}}}{\mathrm{W}_{\mathrm{ij}} / \mathrm{W}_{\mathrm{t}}}
$$

Yu and Qi (2015) classified the RCA index of a commodity into four categories of comparative advantage that is a very strong advantage ( $R C A>2.5)$, strong advantage $(1.25 \leq \mathrm{RCA} \leq 2.5)$, moderate advantage $(0.8 \leq \mathrm{RCA}<1.25)$, and weak disadvantage (RCA $<0.8)$.

Export Product Dynamic (EPD) analysis aims to determine the position of a country in the world market by showing how much its strength or its ability to export (Wardani et al., 2018). The determination of EPD's position is determined by comparing changes in market share over time and the dynamics of exported products. This change in market share indicates whether a country has a competitive advantage in these products or not (Estherhuizen, 2006). 
$\mathrm{X}$-axis: Growth in market share of total exports (Indonesia)

$\frac{\sum_{t=1}^{n}\left(\frac{X_{i j}}{W_{i j}}\right)_{t} \times 100 \%-\sum_{t=1}^{n}\left(\frac{X_{i j}}{W_{i j}}\right)_{t-1} \times 100 \%}{T}$

Y-axis: Growth in product market share

$\frac{\sum_{t=1}^{n}\left(\frac{X_{t}}{W_{t}}\right)_{t} \times 100 \%-\sum_{t=1}^{n}\left(\frac{X_{t}}{t}\right)_{t-1} \times 100 \%}{T}$

Description:

$\mathrm{x}_{\mathrm{ij}}=$ export value of Indonesian CCO to destination countries

$x_{t}=$ total value of Indonesian exports to destination countries

$\mathrm{W}_{\mathrm{ij}}=$ export value of world CCO to destination countries

$W_{t}=$ total value of world exports to destination countries

$\mathrm{T}=$ number of years

Analysis of the factors that affect the competitiveness of Indonesian CCO to destination countries

Panel data regression analysis was used to estimate the factors that influence the competitiveness of Indonesian CCO to destination countries. In this study, the results of the Indonesian RCA index were used as the dependent variable.

$$
\begin{aligned}
& \operatorname{LnRCA}_{i j}=\alpha_{i j}+\beta_{1} \operatorname{LnQ}_{i j}+\beta_{2} \operatorname{LnTO}_{j}+ \\
& \beta_{3} \operatorname{LnRER}_{\mathrm{ij}}+\beta_{4} \operatorname{LnX} X_{\mathrm{pj}}+\mathrm{e}_{\mathrm{ij}} \\
& \mathrm{RCA}_{\mathrm{ij}}=\text { Indonesian RCA index to } \\
& \text { destination countries } \\
& \alpha_{\mathrm{ij}} \quad=\text { Intercept } \\
& \beta_{1}-\beta_{4}=\text { Regression coefficient } \\
& \mathrm{Q}_{\mathrm{ij}} \quad=\text { Export volume of Indonesian } \\
& \text { CCO to destination countries } \\
& \text { (Kg) }
\end{aligned}
$$

\section{RESULTS AND DISCUSSION}

The results show that Indonesian CCO had competitiveness in the five destination countries (the United States, the Netherlands, Malaysia, China, and Singapore). The average of RCA index in each country showed that Indonesian CCO had a very strong comparative advantage and EPD analysis also showed that Indonesian CCO was in the rising star position in the Netherlands,

Table 1. Data sources in this study

\begin{tabular}{ll}
\hline \multicolumn{1}{c}{ Data } & \multicolumn{1}{c}{ Sources } \\
\hline Export value of CCO and total value of export & UNComtrade (comtrade.un.org) \\
Exchange rate & The United Nations Conference on Trade and \\
& Development (unctad.org) \\
GDP of destination countries & The World Bank (worldbank.org) \\
\hline
\end{tabular}


Table 2. Export Product Dynamic (EPD) Classification

\begin{tabular}{ccc}
\hline Share of Country's Export in & \multicolumn{2}{c}{ Share of Product in World Trade (Y) } \\
\cline { 2 - 3 } World Trade $(\mathrm{X})$ & Rising/ Dynamic $(+)$ & Falling/ Stagnant $(-)$ \\
\hline \multirow{2}{*}{ Rising/ Competitive $(+)$} & Optimal & Vulnerable \\
& "Rising Stars" & "Falling Stars" \\
Falling/ Non Competitive (-) & Weakness & Restructuring \\
\end{tabular}

Source: Estherhuizen (2006)

Malaysia, China, and Singapore (table 3). This shows that Indonesian $\mathrm{CCO}$ is a dynamic product in those destination countries where it can grow rapidly and characterized by the increasing demand in those destination countries. The increasing demand for coconut oil is along with many discoveries about alternative renewable energy sources derived from vegetable oil. Research says that biodiesel production from coconut oil is relatively higher and it has much better lubrication properties than other vegetable fuels (Hossain et al., 2012). Health specialists also said that coconut oil has health benefits for weight loss, cholesterol reduction, prevention of cardiovascular disease, and anti-inflammatory effects (Lima and Block, 2019). In the United States, Indonesian $\mathrm{CCO}$ was in a falling star position which indicates that Indonesian CCO had a competitive advantage, but the commodity of Indonesian CCO in the United States market was not dynamic. It also indicates that on average there is an increased growth in Indonesian CCO market share but it is not accompanied by an increase in demand in the United States. RCA trend of Indonesian CCO was considerably fluctuated during 1996-2017. Analysis of RCA trends in the United States and China showed a positive trend but in the Netherlands, Malaysia, and Singapore, the RCA trend of Indonesian CCO had decreased. The increasing trend of RCA in the United States shows that Indonesian CCO were commodities that had a strong comparative advantage, but based on export dynamic, Indonesian CCO was in vulnerable position. Ningsih and Kurniawan (2016) stated that a product which has increased in RCA index may not be categorized as a product with good export performance. A product with an increased RCA value can be said to be "falling star" if the increase in RCA is caused by a decrease in the share of export destinations which means the market size for the product is getting smaller. The decrease in size or the decrease of CCO market demand in the United States might be due to the 
Table 3. The average results of RCA index and EPD of Indonesian CCO in 1996-2017

\begin{tabular}{ccccc}
\hline \multirow{2}{*}{ Country } & RCA & \multicolumn{2}{c}{ EPD } & Market \\
\cline { 3 - 4 } & Index & X-axis & Y-axis & Position \\
\hline United States & 27.90 & 40.14 & -0.25 & Falling Star \\
Netherlands & 42.78 & 15.74 & 0.07 & Rising Star \\
Malaysia & 20.69 & 8.45 & 5.99 & Rising Star \\
China & 44.60 & 45.96 & 1.40 & Rising Star \\
Singapore & 4.41 & $501,646.6285$ & 1.08 & Rising Star \\
\hline
\end{tabular}

Source: Secondary Data Analysis, 2019

fact that the United States was also a competitor of Indonesia in the vegetable oil industry. The United States was one of the largest exporters of soybean oil in the world. During this period the United States might want to maintain its trade by reducing $\mathrm{CCO}$ imports from Indonesia.

China was the third largest market share for Indonesian CCO after the Netherlands and the United States. The increasing RCA trend of Indonesian CCO and the rising star position in China were caused by the demand for its derivative products which is made from coconut oil. In China, Indonesia was one of the largest exporting countries for commodities such as palm oil, coconut oil, cocoa products, and rubber (Riyani et al., 2018). The average Indonesian CCO market share in China in 2000-2017 was 49.92\% (UN Comtrade, 2019). Most of Indonesian agricultural exports to China are raw or intermediate materials which will be used as industrial raw materials in China. Therefore, despite there was an increasing in import tariffs, the demand for Indonesian agricultural commodity exports from China remained high to maintain the sustainability of the domestic industrial production process in China (Riyani et al., 2018).

The declining RCA trend of Indonesian CCO in the Netherlands and Malaysia occurred in which these two countries were not only as importing countries but also as re-exporting countries. Sukmaya (2017) found that the relationship between Indonesian and the Netherlands exports is complementary in both the compensated and uncompensated elasticity. This means that if the export price of the Netherlands CCO rises, the export share of Indonesian CCO will decrease. So it is necessary to do cooperation between the two countries to reduce the negative impact of the crude coconut oil trade. On the other side, Malaysia is one of the ten largest countries in coconut production (FAOSTAT, 2019). The declining RCA trend of Indonesian CCO could have been happened because Malaysia 
tried to increase the production and specialization of its coconut oil so that it was able to increase exports and reduce CCO imports from Indonesia.

Post-harvest processing machineries technologies has been developed by The Malaysian Agricultural Research and Development Institute (MARDI) to facilitate the production systems include decorticating of coconut husk, dehusking of coconut, and processing systems for young coconut and virgin coconut oil (Hamid et al., 2018). Beside that, the national government of Malaysia has approved a funding allocation totaling RM 71,5 million for the national investment of the coconut sector (Sangeetha et al., 2019). During the 1996-2014, the production trend of Malaysia's coconut oil increased by 588.7 tons annually (FAOSTAT, 2019), and the CCO export trend in 1996-2017 also increased by US $\$ 738,901$ annually (UNComtrade, 2019). This also proves that in the last five years (2012-2017), export market share of Indonesian CCO in 2012-2017 in Singapore declined fairly high. Indonesia lost almost 20\% of its market share in that period. Based on UNComtrade (2019), in recent years Malaysia has captured the CCO market share of Indonesia in Singapore, and now Malaysia has become the main supplier of CCO in Singapore and controlled more than $80 \%$ of the CCO export market share in Singapore. Based on the results of the analysis, the factors affecting the competitiveness of Indonesian $\mathrm{CCO}$ to the destination countries during 1996-2017 were exported volume of Indonesian CCO, trade openness, and export value of Philippines CCO, while real exchange rate had no significant effect to Indonesian CCO competitiveness. The export volume had a positive influence on the RCA of Indonesian CCO, where every one percent increase in the export volume will increase by $0.87 \%$ RCA of Indonesian CCO. This result is consistent with Lotfi and Karim (2016) that export quanity can influence the export competitiveness. Increased competitiveness can be defined as the success to compete with competitors. A company or country will be competitive if it can sell products that meet the requirements of foreign demand (in terms of price, quantity, and quality), so that it can generate more profits. The increasing of export volume will increase the RCA of Indonesian CCO, and vice versa (figure 1 ). When the export volume of CCO in the destination countries increase, this implies that there is an increase in demand from the destination countries. In this case, Indonesia must be able to maintain the availability of $\mathrm{CCO}$ for more export expansion with the aim of Indonesia being able to maintain its market and be able to compete in 
Table 4. The results of the analysis of factors that affect the competitiveness of Indonesian CCO to destination countries in 1996-2017

\begin{tabular}{lccccc}
\hline \multicolumn{1}{c}{ Variable } & $\begin{array}{c}\text { Expected } \\
\text { Value }\end{array}$ & Coefficient & Std. Error & t-Statistic & Probability \\
\hline $\mathrm{C}$ & & -1.346472 & 3.772988 & -0.356871 & 0.7219 \\
$\mathrm{LnQ}_{\mathrm{ij}}$ & + & 0.725931 & 0.035427 & 20.49116 & $0.0000^{* * *}$ \\
LnTO $_{\mathrm{j}}$ & + & -0.510048 & 0.290617 & -1.755052 & $0.0823^{*}$ \\
$\mathrm{Ln} \mathrm{RER}_{\mathrm{ij}}$ & + & -0.607841 & 0.425500 & -1.428536 & $0.1562^{\text {ns }}$ \\
LnX $_{\mathrm{pj}}$ & - & -0.191221 & 0.054643 & -3.499450 & $0.0007^{* * *}$ \\
\hline $\mathrm{R}^{2}$ & & 0.878951 & & & \\
Adjusted R & & 0.869363 & & & \\
Prob (F-statistic) & & 0.000000 & & & \\
\hline
\end{tabular}

Source: Secondary Data Analysis, 2019

Description: ${ }^{* * *}$ ) Significant at $1 \%$ probability level, (t-table: 2,623 )

*) Significant at 10\% probability level, (t-table: 1,659)

ns) Non significant

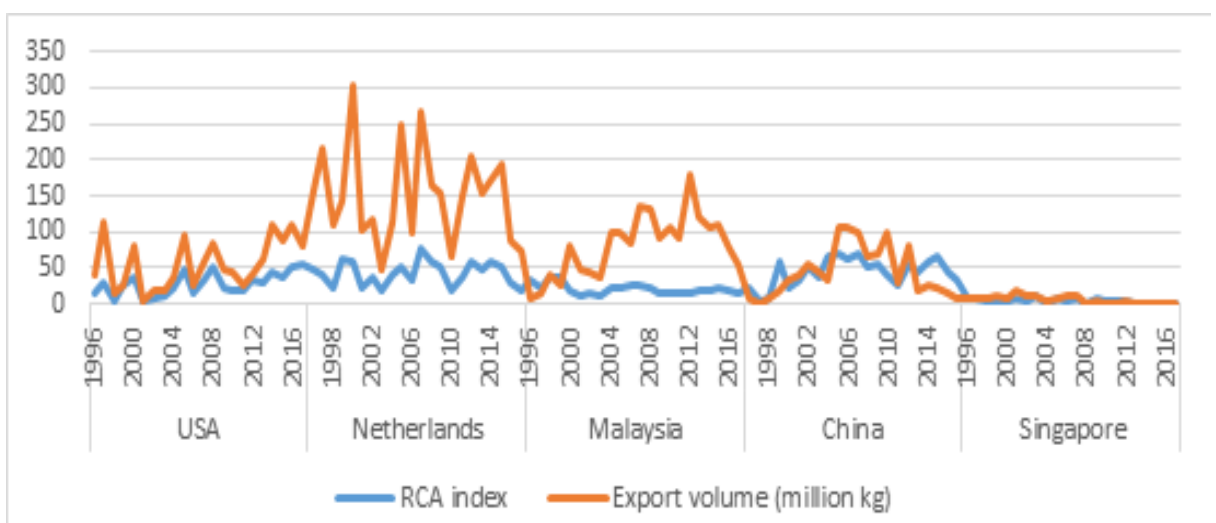

Figure 1. RCA of Indonesian $\mathrm{CCO}$ and export volume in destination countries in 1996-2017

Source: Secondary data analysis, 2019

the destination countries. According to Cvetković and Petrović-Ranđelović (2017) the size and quality of exports can determine competitiveness. The size of exports implies penetration into foreign markets and continuing the same expansion. Export volume and export dynamics can determine the size of the exports. The export volume is considered to be quantities of exported products which indicates its strength in terms of capacity, resources, and efficiency. In this regard, export volume to some extent is a measure of a comparative advantage of one sector.

Openness implies the removal or reduction of restrictions or barriers on the free exchange of goods between nations (Kiganda, 2017). Trade openness is expected to have postive impact to 


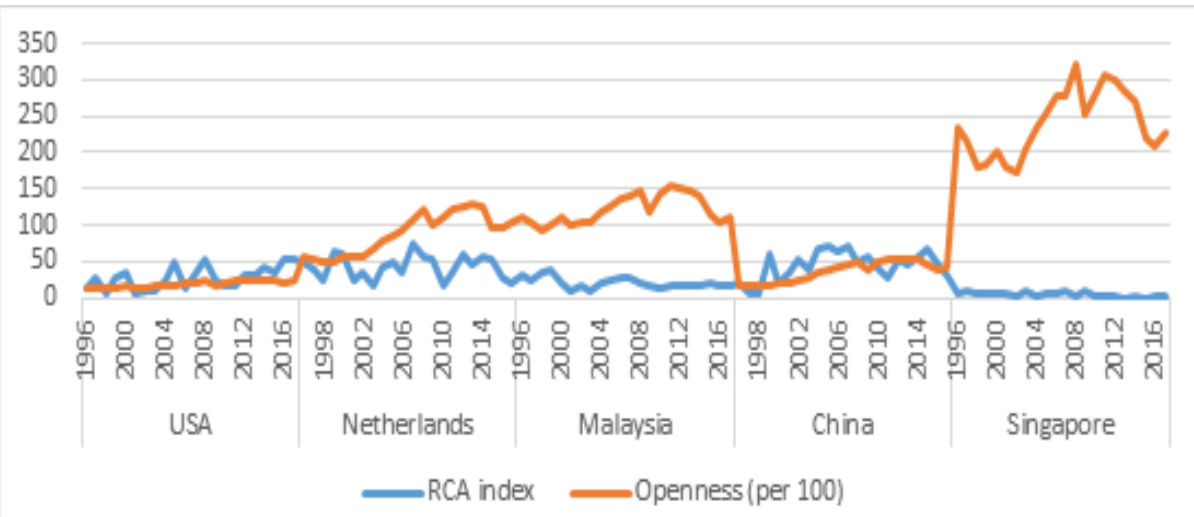

Figure 2. RCA of Indonesian CCO and trade openess in destination countries in 1996-2017

Source: Secondary data analysis, 2019

international trade. It is is calculated by the sum of exports and imports divided by GDP. Some research said that the higher the openness, the greater the exports and imports of a country. Trade openness is positively and significantly contributing to exports and imports growth of Pakistan (Chaudhary and Amin, 2012). Trade openness of the Regional Comprehensive Economic Partnership (RCEP) region also had positive and significant impact on Indonesian food industry exports. It means that the more open a country in the RCEP region to trade, the more Indonesian food industry exports increase (Wardani et al., 2018).

Recently, the impact of trade openness is still being debated. Some found positive, negative or insignificant effect to export and import (Arumta, et al., 2019). This study found that the increasing trade opennes from importing countries might decrease the RCA of Indonesian CCO exports as figure 2 showed. Trade openness from importing countries had negative effect to Indonesian CCO competitiveness where one percent increasing of trade openness will decrease by $0.51 \%$ Indonesian CCO competitiveness.

As well as Arumta et al. (2019), the impact of trade opennes was negative to Indonesian cut flower export.

Following the theory of comparative cost advantage, trade openness permits import of goods and services at a lower cost than they could be produced (Kalu and Joy, 2015). This is a great opportunity for Indonesia to expand CCO exports in destination countries. However, increased openness will make competitive effects. Not only from CCO producers but also from other vegetable oil producers who can substitute coconut oil. All CCO 
producers will compete to export their products to opened countries. A negative sign might occur because Indonesia is losing in competing with competitors in the destination markets on the CCO commodity. It has enabled countries to look for the good and cheapest things from around the world and offer the best deals to consumers (Lamaj, 2015). In fact, in recent years Malaysia has captured the Indonesian CCO market share in Singapore.

Philippines, Sri Lanka, and Malaysia are competitors for Indonesian $\mathrm{CCO}$ commodity in the main destination countries. According to the Asian and Pacific Coconut Community (APCC), exports of Indonesian coconut products are still lower compared to the main competitor countries (the Philippines). However, when compared to the level of $\mathrm{CCO}$ export prices between the two countries, the price of Indonesian CCO is cheaper than thePhilippines. This indicates that the influence of non-price factors is still quite significant. Factors related to product quality, high transportation costs, and the complexity of export procedures are thought to have contributed to the export of Indonesian CCO that have not been maximized (Departemen Pertanian, 2005). The export share of Philippines CCO during 1996-2017 in the United States and the Netherlands were around $71 \%$ and $61 \%$ respectivly, while the export share of Indonesian CCO were only $23 \%$ in he United States and 29\% in the Netherlands (UNComtrade, 2019). The main quality problem associated with coconut oil is contamination. The Netherlands as the largest CCO importer country sets several quality requirements for coconut oil. The coconut oil should be cleaned of metals, dirt and other foreign material, and for organic coconut oil must comply with organic standards for the production of the raw material: no use of synthetic pesticides, use of natural fertilisers, natural control of weeds, full traceability, internal control system, etc. (CBI, 2016).

The export value of Philippines CCO as a competitor greatly affects the competitiveness of Indonesian CCO. The increase in export value of Philippines CCO had a negative effect on the competitiveness of Indonesian CCO. Every one percent increase in the export value of Philippines CCO will decrease by $0.19 \%$ RCA of Indonesian CCO. The increase in the export value of Philippines CCO had reduced the competitiveness of Indonesian CCO in 2010 and in the past few years in the Netherlands and several other destination countries (figure 3).

The existence of a reliable and strong competitor is a driving force in providing pressure between companies to compete and innovate in order to improve their competitiveness 


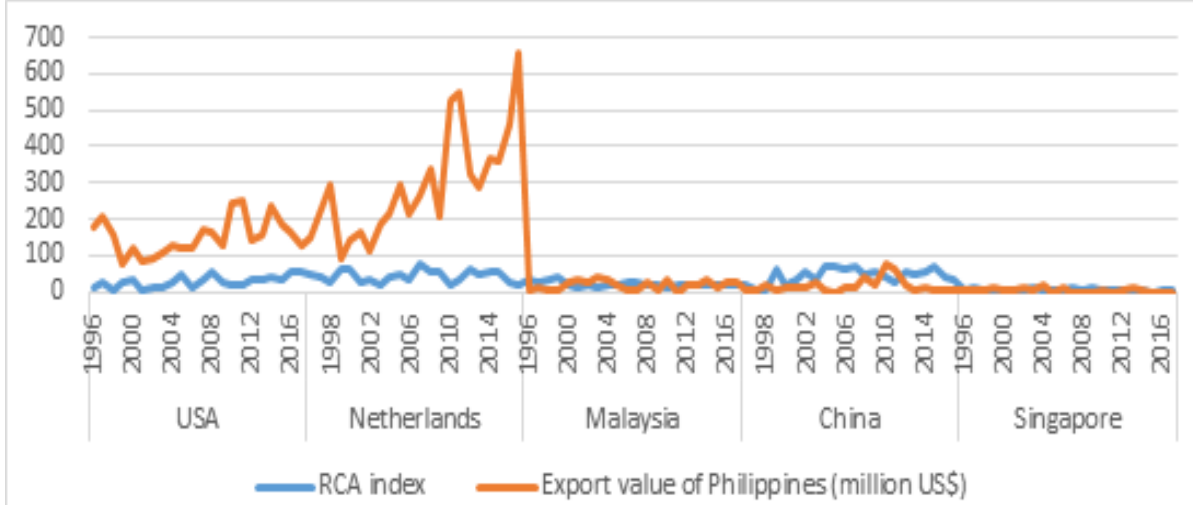

Figure 3. RCA of Indonesian CCO and export values of Philiippines CCO in destination countries in 1996-2017

Source: Secondary data analysis, 2019

(Pudyastuti et al., 2018). In line with previous research, Radityo et al. (2014) stated that competitors will affect the export competitiveness where the increasing market share of competitors in the world can reduce the export competitiveness.

\section{CONCLUSION AND SUGGESTION}

Indonesian had competitiveness in the five destination countries (the United States, the Netherlands, Malaysia, China, and Singapore). RCA index in each destination country showed that Indonesian $\mathrm{CCO}$ had a very strong comparative advantage. EPD of Indonesian $\mathrm{CCO}$ was in a rising star position in the Netherlands, Malaysia, China, and Singapore, which shows that Indonesian CCO was a dynamic product in the world where its product grows rapidly and characterized by increased demand in the world market. In the United
States, Indonesian CCO is in a falling star position which indicates that Indonesian CCO has a competitive advantage, but the commodity of Indonesian CCO in the United States market is not dynamic. The export volume of Indonesian CCO had positive effect, while trade opennes of importing countries and export value of Philippines CCO had negative effect on the competitiveness (RCA) of Indonesian CCO

As one of the efforts to improve the competitiveness of Indonesian CCO export, the government and exporters need to know and choose which markets are the main priorities to be developed. The trade openness of the importing countries must be utilized to be a privilege to increase the export and competitiveness of CCO. On the other hand, the trade openness of the importing countries must be watched out because if the trade of the 
importing countries are more open, the competition of $\mathrm{CCO}$ will be tighter. It is very important to maintain the quality, quantity, and continuity of CCO according to the needs of the importing country. The government and $\mathrm{CCO}$ exporters need to lobby the destination countries to import CCO from Indonesia, and to convince the destination countries, the quality of the CCO needs to be improved, so that Indonesian CCO will become more competitive than others.

\section{REFERENCES}

Arumta, N., Mulyo, J. H., \& Irham. (2019). The Export Determinants of Indonesian Cut Flower in The International Market. Agro Ekonomi, 30(1), 41-52.

Balassa, B. (1965). Trade Liberalization and Revealed Comparative Advantage. Manchester School, 33, 99-123.

Bustami, B. R., \& Hidayat, P. (2013). Analisis Daya Saing Produk Ekspor Provinsi Sumatera Utara. Jurnal Ekonomi Dan Keuangan, 1(2), 56-71.

CBI. (2016). Coconut Oil in the Netherlands. Netherlands.

Chaudhary, M. A., \& Amin, B. (2012). Impact of Trade Openness on Exports Growth, Imports Growth and Trade
Balance of Pakistan. Forman Journal of Economic Studies, 8: 63-81.

Cvetković, M., \& Petrović-Ranđelović, M. (2017). The Analysis of Agricultural Products Export Competitiveness of the Republic of Serbia Based on the RCA Index. Economic Themes, 55(3), 399-420.

Departemen Pertanian. (2005). Prospek dan Arah Pengembangan Agribisnis Kelapa. (Badan Litbang Pertanian, Ed.). Jakarta.

Djoni, Darusman, D., Atmaja, U., \& Fauzi, A. (2013). Determinants of Indonesia's Crude Coconut Oil Export Demand. Journal of Economics and Sustainable Development, 4(14), 98-106.

Estherhuizen, D. (2006). An Evaluation of The Competitiveness of the South African Agribusiness Sector. Dissertation. University of Pretoria.

FAOSTAT. (2019). Production (Crops) Coconuts Commodity Statistic. Retrieved from http://www.fao. org/faostat/en/\#data/QC

Hamid, M. A., Ahamad, W. M. A. W., \& Sahari, Y. (2018). National Coconut Conference 2018: Empowering Coconut Industry. In Mechanisation Package for Coconut Trough 
Innovate Technology (p. 34). Perak, Malaysia.

Hossain, M. A., Chowdhury, S. M., Rekhu, Y., Faraz, K. S., \& Islam, M. U. (2012). Biodiesel from Coconut Oil: a Renewable Alternative Fuel for Diesel Engine. International Journal of Chemical and Molecular Engineering, 6(8), 524-528.

Kalu, U. D., \& E, A. Joy. (2015). Does Trade Openness Make Sense? Investigation of Nigeria Trade Policy. International Journal of Academic Research in Economics and ManagementSciences, 4(1), 6-21.

Kementerian Perdagangan. (2013). Market Brief: Kopra dan Olahannya di Jerman. Germany: Indonesia Trade Promotion Center Hamburg.

Kiganda, E. (2017). Analysis of The Relationship Between Trade Openness and Economic Growth Analysis of The Relationship Between Trade Openness and Economic Growth in Kenya. Journal of Economics and Sustainable Development, 8(2), 121-137.

Lamaj, J. (2015). The Impact of International Trade and Competition Market on Developing Countries. Italy.
Lima, R. da S., \& Block, J. M. (2019). Coconut Oil : What Do We Really Know About It So Far? Food Quality and Safety, 3(2), 61-72.

Lotfi, B., \& Karim, M. (2016). Competitiveness Determinants of Moroccan Exports: Quantity-Ased Analysis. International Journal of Economics and Finance, 8(7), 140-148.

Ningsih, E. A., \& Kurniawan, W. (2016). Daya Saing Dinamis Produk Pertanian Indonesia di ASEAN. Jurnal Ekonomi KuantitatifTerapan, 9(2), 117-125.

Pilinkiene, V. (2016). Trade Openness, Economic Growth and Competitiveness. The Case of The Central and Eastern European Countries. Inzinerine EkonomikaEngineering Economics, 27(2), 185-194.

Pudyastuti, P. A., Sambodo, H., \& Windhan, K. (2018). Analisis Daya Saing Ekspor Komoditas Udang Indonesia di Pasar Eropa Tahun 2008-2016. Seminar Nasional dan Call for Paper Sustainable Competitive Advantage (SCA) 8, 8(1), 1-15. 
Radityo, S. I., Dwiastuti, R., \& Muhaimin, A. W. (2014). Competitiveness of Indonesian Natural Rubber at World Market. Habitat, XXV(3), 143-150.

Riyani, Darsono, \& Ferichani, M. (2018). Analisis Permintaan Ekspor Komoditas Pertanian Indonesia oleh Pasar Tiongkok. AGRARIS: Journal of Agribusiness and Rural Development Research, 4(2), 120128.

Sangeetha, J., Thangadurai, D., Ching, G. H., \& Islam, S. (2019). Revitalizing Coconut Industry In Malaysia. In Biodiversity and Conservation: Characterization and Utilization of Plants, Microbes and Natural Resources for Sustainable Development and Ecosystem Management. Canada: Apple Academic Press Inc.

Sari, P. N., \& Hartono, S. (2010). Analisis Dinamika Ekspor Minyak Nilam Indonesia ke Amerika Serikat. Agro Ekonomi, 17(1), 19-28.
Sukmaya, S. G. (2017). Analisis Permintaan Minyak Kelapa (Coconut Crude Oil) Indonesia di Pasar Internasional. AGRARIS: Journal of Agribusiness and Rural Development Research, 3(1), 1-8.

Turukay, M. (2009). Analisis Permintaan Ekspor Crude Coconut Oil Indonesia di Pasar Dunia. Jurnal Budidaya Pertanian, 5(1), 40-49.

UNComtrade. (2019). Commodity Statistic. Retrieved from https:// comtrade.un.org/data/

Wardani, M. A., Mulatsih, S., \& Rindayati, W. (2018). Competitiveness and Factors Affecting Indonesian Food Industry's Export to Regional Comprehensive Economic Partnership. Etikonomi, 17(2), 185-198.

Yu, C., \& Qi, C. (2015). Research on The Complementarity and Comparative Advantages of Agricultural Product Trade Between China and CEE Countries. Journal of Service and Management, 8(2), 201-208. 